\title{
The registered nurse in the field of substance abuse - invisible and generic or distinct and specific?
}

\author{
Anne Line Granamo \\ Spesialsykepleier i rusproblematikk
}

Nordre Follo kommune

\section{Unni Knutstad}

Førsteamanuensis

Institutt for sykepleie og helsefremmende arbeid, Fakultet for helsevitenskap, Oslomet - storbyuniversitetet

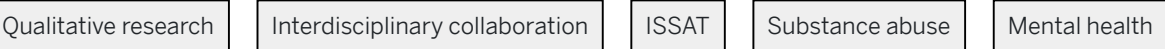

\section{Summary}

Background: Earlier research has found that registered nurses who work in the field of substance abuse describe their role as being indistinct. They find it difficult to define the specialist competence of a registered nurse. This field requires an interdisciplinary approach encompassing medical expertise as well as expertise in social work and mental health. It can be difficult to give a clear definition of the role that registered nurses play in the span between these disciplines.

Objective: To describe and expound the work of registered nurses in Interdisciplinary Specialized Substance Abuse Treatment (ISSAT). The research question was: 'What are the registered nurses' and other ISSAT professionals' experiences and expectations of the role of the nurse in ISSAT?'

Method: The study has an explorative design and takes an inductive approach, the object being to investigate and describe a phenomenon, i.e. the function of registered nurses in ISSAT teams. The data were collected in semistructured individual interviews with five registered nurses and six informants from the other ISSAT professions. The data have been analysed in accordance with Malterud's descriptions of systematic text condensation.

Results: The study shows consistency between the informants' descriptions of the registered nurses' function. The registered nurses' somatic knowledge is highlighted, as is their milieu therapy expertise. Their contributions to the interdisciplinary collaboration appear to be distinct and well recognised. Nevertheless, it is also evident that the clinical practice of registered nurses varies and that, as a group, they are seeking to adopt a more uniform profile. The registered nurses want a common nursing platform and clear expectations.

Conclusion: The study shows that registered nurses have a distinct function within the interdisciplinary team and a clear role in the interdisciplinary collaboration. Their somatic skills, milieu therapy expertise and the interrelationship between the two, are highlighted as their most important contribution. National guidelines and standard patient pathways point to a more somatic approach to patients, and the contributions of registered nurses as a group, will be important. Registered nurses would benefit from a more uniform profile vis-à-vis patients, which may strengthen the provision and quality of the services. 
Registered nurses (RNs) are one of the professions that contribute to Interdisciplinary Specialized Substance Abuse Treatment (ISSAT). Such treatment draws on expertise in social work, psychology and medicine or healthcare, depending on the patients' individual problems and pathways. The treatment includes detoxification, screening and investigation, outpatient treatment, community-based treatment, residential inpatient treatment and peripatetic follow-up/ treatment (1).

Milieu therapy is a recommended form of therapy in ISSAT (2), and entails exploiting the opportunities that spring from daily interactions with other people (3). Specifically, the therapist seeks to make use of the resources that are available in a person's surroundings, and switches between providing support and presenting challenges in a relationship that is characterised by recognition and respect. The goal is to facilitate mental, physical, social and spiritual growth, and to strengthen self-care (4).

The RNs' function, or their tasks and responsibilities, are described in the national guidelines for graduate nursing courses (5). RNs train to meet patients' basic human needs, promote health, prevent and treat disease, alleviate suffering and ensure a dignified death.

Kirkevold (6) points out that nursing theories, like self-care theories, are practical theories. According to self-care theory, the RN's function is to support sick or injured patients by meeting the basic needs that the patients themselves have insufficient resources to meet. The goal is self-care, so that patients do not need to rely on assistance. Creating a relationship between the patient and the $\mathrm{RN}$ is essential to providing care. This relationship must be characterised by respect and recognition.

The RNs' function will depend on their competence. Grimen (7) maintains that what distinguishes professions is that they typically choose their knowledge base according to the task at hand. It is the practical tasks that determine what expertise is required in different scenarios.

The former framework plan for nursing education describes the content of nursing courses in terms of medical, nursing and social sciences topics, including psychology (8). This means that the RNs' area of competence comprises aspects from the other disciplines that contribute to ISSAT, and this may give rise to a blurring of lines vis-a-vis the other professions, with doctors providing medical expertise, psychologists providing mental health expertise and social workers providing expertise in social sciences. The respective descriptions of the various professions also include general and overlapping elements.

According to the recently approved national guidelines for graduate courses in health and social care (5, 9-12), doctors should investigate, diagnose, treat, follow up and prevent disease in individual patients. Psychologists should understand, investigate, diagnose, treat and assess mental health problems in individuals, families and groups, while also working in health promotion and disease prevention.

Social workers should assist individuals, families or groups to prevent, reduce and cope with social and health-related problems. The description of the social educators' specific competence refers to milieu therapy, habilitation and rehabilitation, health promotion and health support.

All of these professions are represented in interdisciplinary teams, and RNs need to find their role and unique place among them. Interdisciplinary collaboration requires mutual respect and recognition, and the specific competence of each profession should be made clear (15). Trusting and respecting your own competence generates respect from colleagues. Having a common understanding of one another's roles in patient work will lead to respect for other occupational groups (14). Perceptions and expectations of teamwork may differ among RNs and other professions. RNs may have different ideas from doctors about what constitutes good teamwork (15).

Our study was conducted in a residential inpatient treatment setting with clinical staff present at all times (1). Earlier studies of RNs in the field of substance abuse describe the RNs' role as being indistinct, and that it is difficult to define the RNs' specific competence (16-18).

Karlsson and Kim (16) reported in their study about nursing in primary mental health care and substance abuse services that RNs consider their own remit to be open-ended, and that their roles and functions to some extent are indistinct, in that there are overlaps with those of other professions.

Melby et al. (17) found in their study about RNs working in mental health and ISSAT that RNs find it difficult to define their own specific professional contributions to the interdisciplinary collaboration. 
Olsvold (19) describes the RNs' responsibilities on inpatient wards as organisationally unlimited, and found that RNs assumed responsibility for informally delegated generic tasks on top of their specific nursing tasks. Kleiveland (20), who studied the role of RNs in accident and emergency departments, reported similar findings.

More research appears to be needed on the nature of RNs' professional contributions to ISSAT.

\section{The objective of the study}

The study aimed to explore the expectations and experiences of the RNs' function within ISSAT collaborations. Earlier studies have generally focused on the RNs' own experiences and to a lesser degree the experiences of their collaborative partners. This study therefore seeks to increase our understanding of the RNs' function by also interviewing their colleagues in order to explore the views and expectations held by the various professions.

\section{Research question}

'What are the registered nurses' and other ISSAT professionals' experiences and expectations of the role of the nurse in ISSAT?'

\section{Method}

The study has an explorative design and takes an inductive approach, the goal being to investigate and describe a phenomenon: the RNs' function within ISSAT. Data were collected by conducting semi-structured individual interviews with five RNs and six informants from other ISSAT professions.

\section{Sample and recruitment}

Staff at two ISSAT residential inpatient units were invited to participate. Informants were recruited through two rounds of emails sent out by the supervisor, plus an information meeting. The sample was strategic rather than representative (21). In order to shed light on the research question from an interdisciplinary perspective, the inclusion criteria required informants to be working healthcare personnel who were qualified social workers, doctors, social educators, psychologists or registered nurses.

A total of 14 people accepted the invitation to participate. In order to achieve even distribution between the professions, informants from professions with many volunteers were picked by drawing lots. The informants' experience of working in the field ranged from 12 months to 15 years.

\section{Interviews}

We conducted individual interviews in the period from November 2018 to January 2019 at the informants' place of work. The interviews were semi-structured, and the interview guide consisted of three general topics and seven questions (22).

The main theme was experiences and expectations of the RNs' function, knowledge and tasks. The questions in the interview guide were inspired by the questions used by Melby et al. in their study of the RNs' function within ISSAT and in mental health care (17), and by Kleiveland's study about the RNs' role in accident and emergency departments (20). The interviews were recorded on tape and lasted between 16 and 65 minutes.

\section{Data analysis}

The interviews were transcribed and the data analysed in accordance with Malterud's systematic text condensation methodology (23). We proceeded in the following steps: overall impression, meaning units, condensation and synthesis. The analysis was not a linear process. We moved back and forth between different parts of the empirical material in order to capture ever new aspects (23).

Different experts notice different aspects of any material, and this provides scope for several interpretations and approaches. The text condensation process was therefore discussed within the research team, with supervisors and fellow students in order to validate the analysis.

We divided the informants into two groups: RNs and other healthcare workers. Below, the latter group will be referred to as the healthcare personnel informants. The first author was working in ISSAT during the study, which may have impacted on the results. On the other hand, the second author had no previous experience of ISSAT. 


\section{Data protection and research ethics}

The study was reported to and approved by the Norwegian Centre for Research Data (NSD), reference number 691269. We followed the guidelines for risk and vulnerability analysis in accordance with the General Data Protection Regulation (GDPR). All informants have given their informed consent and confirmed their voluntary participation. Transcripts were anonymised and stored on an encrypted memory chip, and all recordings were deleted after transcription.

\section{Results}

Four main themes emerged from the analysis: 'Expectations of RNs' somatic competence' (bodily phenomena and physical diseases and their treatment), 'Expectations that somatic nursing will be combined with milieu therapy', 'Collaboration with the other professions' and 'RNs want a join professional platform'. See an example of the analytic process in Table 1.

\section{Table 1. Example of analysis}

\section{Meaning unit}

'Well, it's about establishing the situation with respect to nutrition and sleep.'

'And if someone is injured, you know, or needs medication. Then they'll need to administer it, you know, or treat the wound.'

'Some nurses are more focused on somatic aspects, but the surroundings are always there. Some have experience only from substance abuse and psychiatry, you know. But I find that even here you do need a combination of the two.'

'Many have a lot of things to deal with, so you really need to create a good relationship, to make sure they listen to what you say, and perhaps take it onboard a little, and then they manage to make a change rather than you creating, like [...] that you ruin the relationship straight away. It's like 'she only tells me all the things I need to change, so I don't want to co-operate with her anymore'.'

\section{Condensation}

Somatic nursing/

medicine,

basic needs

Nursing care and milieu therapy
The

Exp

of $t$

sor

Exp sor be wit

\section{Expectations of RNs' somatic competence}

All informants agreed that knowledge of physical symptoms, medications and basic human needs forms an important part of RNs' expert contribution to the interdisciplinary collaboration. RNs are expected to have knowledge of anatomy, physiology, pathology, medications, substance abuse, abstinence, overdoses and emergency medicine.

Tasks that were highlighted included patient admission, medicines management, observation, documentation, followup and assessment, initiating relevant interventions and collaboration with the other professions, particularly the doctors. RN informant 10 reflected as follows about substance abuse and medication: 'And then there is our observations in relation to any substance abuse, as well as observations in relation to administered medication.'

\section{«The RNs pointed out that different registered nurses have different levels of somatic corr. there is a need to keep practising tasks and procedures.»}

The RNs pointed out that different registered nurses have different levels of somatic competence and that there is a need to keep practising tasks and procedures. RN informant 9 stressed the importance of somatic competence: 'There's ECG of course, and being alert to completely different things that can also happen, that you should be prepared for. The people here may well suffer a cardiac arrest for reasons other than opioids.' 
In the words of healthcare personnel informant 4: 'If I have a question about anything to do with a medical aspect, I can generally ask the nurses.'

Healthcare personnel informant 2 mentioned that one of the RNs had pointed out to a patient that her legs were swollen. 'That's the sort of thing I don't think about. The nurses have more of that, a kind of basic package that they bring with them. They take more of a somatic view when they engage with patients. As I see it, the most important thing that makes us more of an interdisciplinary team, is that the nurses are much better at all that somatic stuff. Simply because their training has focused more on that.' In other words, the other professions expected RNs to share this knowledge with them.

RNs ensure that the basic needs of patients are met. Sleep, nutrition and safety were highlighted by virtually all informants. Personal hygiene was also mentioned. The RNs themselves stressed that the patients have many challenges and needs, and that RNs have insufficient time at their disposal to follow up on everything. Healthcare personnel informants suggested that RNs feel a great need to help the patients, perhaps even more than necessary.

\section{Expectations that somatic nursing will be combined with milieu therapy}

RNs were expected to contribute to the milieu therapy. Healthcare personnel informant 1 pointed out that RNs need to be available: 'If I'm not available to solve a task, then the nurse needs to make an even greater effort to try milieu therapy or conversation therapy in order to reduce the pressure.'

Several healthcare personnel informants described RNs as being confident in facing the challenges that can arise in everyday situations. Healthcare personnel informant 7 said as follows: 'But my expectations are quite high in relation to substance abuse as well as mental health problems, that's for sure. And I feel that's warranted, because I think they know a great deal.'

\section{«Several healthcare personnel informants described RNs as being confident in facing the $c$ arise in everyday situations.»}

The RNs were keen to point out that working with patients in their own surroundings involves more than having a nice time: 'When you sit there, in their own surroundings, you're actually in a position to spot things. It's not about having a nice time. Yes, you discover things that may be repetitive', said RN informant 3 .

Informants from both groups mentioned several environment-based nursing tasks, such as observations and recording the patient's behaviour, the patient's physical and mental health, offering guidance in everyday situations, generating an interest in new substance-free activities and accompanying patients when, for example, they are going home or attending a court case.

Good milieu therapy can help patients enjoy their treatment and can reduce anxiety, unease and cravings. The concept of 'care' was mentioned several times by most informants when they described the RNs.

The interrelationship between somatic nursing and milieu therapy appeared to be a challenge. Healthcare personnel informant 8 explained: "[It involves] administering medication, following up on the patient and everything that happens in the setting, and all the milieu therapy, which is the backbone of everything here. So the nurses are involved in everything from A to Z. And back again.'

Tasks may conflict. Several RN informants explained that at times they may have to spend long hours in the medicines room, leaving no time for milieu therapy work. RN informant 11 pointed out however that the somatic view can easily be forgotten when the focus is on milieu therapy: 'But you know, there has been a great deal of milieu therapy, so my focus on somatic aspects may well have lapsed.'

However, the RNs in particular pointed to the importance of nursing competence in the community setting. Knowledge of all areas is required, and the RN must be able to see it all in context. One RN mentioned an episode where a patient with a suspected anxiety attack actually had a heart problem. Another RN stressed the importance of inviting the patient to go for a walk rather than offering medication. 


\section{Collaboration with the other professions}

There was broad agreement among the healthcare personnel informants that they depend on the RNs' feedback about patients to be able to do their job: 'They are closer to the patients day-to-day, so I am entirely dependent on frequent talks with them,' said healthcare personnel informant 7 .

It is all about making observations of specific situations and of how the patient is doing: 'And we often discuss the approach to a patient if I have questions about whatever I have read in the records', said healthcare personnel informant 4.

Feedback takes the form of conversations, documentation, meetings and internal messages. The RNs referred to the collaboration as good teamwork. The organisational structure is flat, with minimal hierarchy. RN informant 3 described the collaboration in these terms: 'You know them all well. And they're in the same building, so you can just pop in.'

Some informants reported that tasks were sometimes delegated to them, mainly by the psychologists, that are not strictly speaking RN tasks. However, one RN pointed out that it is up to the RNs themselves to stop this practice. Several described the relationship between RNs and doctors as being particularly good. They pointed out that they come from the same hospital tradition, work well as a team, exchange knowledge and understand each other well.

\section{RNs want a common nursing platform}

Despite the fact that both groups of participants appeared to have clear ideas about their experiences and expectations of RNs, the RN informants were seeking a join professional platform. RN informant 6 said: 'I often miss a shared foundation. A common platform where we all stand together within a clear framework.'

They highlighted the fact that there were considerable individual differences depending on who is on duty, and which tasks are prioritised. RN informant 11 said: 'At times, views differ on how we should be working in the setting. Because we have different ways of going about it. We make our own assessments, as it were. And that means that things turn out different, depending on who's on duty.'

Several healthcare personnel informants agreed. Two of the RNs emphasised that their tasks varied depending on the makeup of the team, and that they miss a more evidence-based approach to their work. RN informant 6 said: 'An awful lot is down to the team, so there is some blurring of boundaries. And because the supervisor can't keep a tab on every single team, you just have to trust the team in the end.'

The RNs stressed that they work well together and learn a lot from each other, and that it is reassuring to work with so many others from the same profession. One of the healthcare personnel informants pointed out that everyone could be better at following existing procedures.

\section{Discussion}

The study suggests that the RNs' ISSAT function and competence involve making assessments and taking action based on the patients' physical condition. This is an important and valued contribution to the interdisciplinary collaboration. It does not imply that the RNs' tasks in relation to the patients' mental health and milieu therapy are ignored.

Milieu therapy is used to capture the signs and symptoms in patients' physical and mental health. The study also suggests that RNs are good at working in partnership with other professions. However, they are seeking a common nursing platform.

\section{Somatic competence is the most important}

All informants described the RNs' somatic competence, their ability to assess the patients' physical condition, as perhaps their most important area of expertise. The RNs' function in ISSAT appears to be that they notice and assess the patients' physical health in addition to performing the relational and therapeutic tasks assigned to them in ISSAT.

Our findings relating to the RNs' somatic competence match Karlsen's study, which highlights the RNs' focus on knowledge about the body (18). However, RNs in other studies, including Karlsen's, report that they feel their competence is not always recognised $(17,18)$. In our study, on the other hand, the RNs' somatic competence is described as being recognised and in demand. 
Other studies also emphasise how RNs' competence varies and that there is a demand for a greater focus on somatic tasks and procedures $(17,18)$. Interdisciplinary continuing education courses in mental health and substance abuse are criticised for their insufficient focus on nursing, which erases the distinction between RNs and other graduates (18, 24, 25).

Our study may indicate that RNs will be able to meet the demand for increased somatic competence set out in national guidelines and standard patient pathways where the primary objectives include better physical health care and lifestyle support $(1,2)$.

\section{Somatic nursing and milieu therapy are not necessarily opposites}

Milieu therapy has been accused of replacing traditional basic nursing care and other nursing tasks (25). However, our study shows that much of the nursing care is provided in the milieu therapy setting when the RNs are present in daily interactions with patients. This is where they build their relationship with the patients, and this relationship forms the foundation for providing care.

Making valuable observations of a physical and psychological nature, providing support to ensure that basic needs are met, and the interrelationship between the two, are examples of tasks performed by RNs in the milieu therapy setting. Other studies also highlight the importance of addressing somatic and psychological issues at the same time $(17,18)$.

\section{«Much of the nursing care is provided in the milieu therapy setting when the RNs are pres interactions with patients.»}

Karlsen (18) points out that because RNs are knowledgeable about the body, they look for other things in their patients than other professions do, and they have been trained to observe signs and symptoms (18). This point is illustrated by the example of the patient that presented with symptoms that suggested anxiety but turned out to be symptoms of heart failure.

These nuances are in line with Kirkevoll's description of the opportunity for bridge-building between the philosophical care theories and the more practical nursing theories (6). RNs must relate to bodily and biological issues as well as human issues, and they must address the complexities that arise from their interrelationship. RNs cannot treat these issues in isolation (6).

The RNs emphasised that they focus on their own discipline when they work in a milieu therapy setting. In other words, milieu therapy does not necessarily conflict with being alert to physical and somatic aspects.

\section{Good teamwork and minimal hierarchy}

Having a common understanding of one another's roles in patient work will lead to respect for other occupational groups (15). The various informants' descriptions of RNs were generally in agreement, and the healthcare personnel informants pointed to the importance of the RNs' assessments and observations.

\section{«The RNs described good teamwork with the other professions, and minimal hierarchy.»}

These findings contrast with other studies, where RNs report that several colleagues favour their own impressions of patients and attach little importance to observations made by RNs (17). The RNs in our study described good teamwork with the other professions, and minimal hierarchy. It is easy to call in on other team members, and they find that they are acknowledged and listened to.

The other professions reported that they work well with the RNs in that they are available to answer questions, assist with various tasks and work in close partnership with the patients. Interdisciplinary collaboration is dependent on all of these factors: mutual respect and recognition, professional expertise, a confident professional identity and clarity surrounding each profession's special competencies (13). The distribution of tasks among the various professions was described as being clear.

\section{The need for a common nursing platform}

Within the nursing discipline there is an ongoing debate about evidence-based practice versus professional discretion and individual and scenario-based nursing (26). In our study, the RNs' role appeared to be clear, but the RN informants were nevertheless seeking a join professional platform for their specific discipline. It is not clear from the data whether in our context this refers to insufficient procedures or non-compliance with existing procedures. 
One interpretation may be that the RNs want patients to be offered a uniform service, and that the priorities they make should depend less on individual discretion. However, this could limit their professional discretion. This and other earlier studies show that RNs tend to take on too many tasks $(16,27)$.

The informants emphasise that some tasks have a negative effect on the quality of their work. Although the RNs' competence and function appear to be clear, their remit is relatively open-ended, allowing them to decide how to prioritise and perform their tasks. The need for a common professional platform for the discipline could therefore help to ensure that patients receive a more equitable service.

\section{Weaknesses of the study}

The study has few informants; only one or two from each of the ISSAT professions, with the exception of the six RN informants. The sample was solely based on the informants' education and included no other characteristics.

\section{Conclusion}

This study's informants had clear expectations of RNs. They highlighted somatic knowledge, milieu therapy expertise and the ability to combine the two, as well as making observations, conducting assessments and providing feedback to colleagues. RNs are discussion partners and advisors. The healthcare personnel informants highlighted nursing care as a valuable contribution to the interdisciplinary collaboration.

This study has clarified the RNs' function in ISSAT through the RNs' and their colleagues' emphasis on somatic competence in the treatment of patients in addition to milieu therapy work.

\section{The study's contribution of new knowledge}

- Earlier research shows that the RNs' function and special competence are indistinct in interdisciplinary collaborations. Tht informants rather than their collaborative partners from other professions.

- We interviewed RNs and their colleagues in Interdisciplinary Specialized Substance Abuse Treatment (ISSAT) teams. This healthcare personnel who were qualified doctors, social educators, social workers or psychologists, in addition to the RNs. analysis of the interviews.

- The RNs and their collaborative partners have a common perception of the RNs' function in ISSAT. The knowledge genera1 raise awareness among RNs, their colleagues and supervisors of the vast potential that lies in providing a high standard of 1 people with mental health or substance abuse problems. In a field where national guidelines and standard patient pathway: approach to patients, RNs must be considered important contributors.

\section{References}

1. Helsedirektoratet. Rusbehandling (TSB) pakkeforløp. Oslo: Helsedirektoratet; 2018. Available at: https://helsedirektoratet.no/retningslinjer/rusbehandling-tsb-pakkeforlop (downloaded 30.04.2019).

2. Helsedirektoratet. Nasjonal faglig retningslinje for behandling og rehabilitering av rusmiddelproblemer og avhengighet. Oslo: Helsedirektoratet; 2016. Available at: https://helsedirektoratet.no/retningslinjer/behandling-ogrehabilitering-av-rusmiddelproblemer-og-avhengighet (downloaded 30.04.2019).

3. Fredheim KN. Implementering av kognitiv miljøterapi i akuttpost i psykisk helsevern. Tidsskrift for Norsk psykologforening. 2009;46(2):161-7.

4. Lillevik OG, Øien L. Hva er miljøterapi? Sykepleien. 2015;103(5):60. DOI: 10.4220/Sykepleiens.2015.54066

5. $\quad$ Forskrift 15. mars $2019 \mathrm{nr} .412 \mathrm{om}$ nasjonal retningslinje for sykepleierutdanning. Available at: https://lovdata.no/dokument/SF/forskrift/2019-03-15-412 (downloaded 20.09.2020).

6. Kirkevold M. Er det på tide å bygge bro over kunnskapskløften i sykepleiefaget? I: Alvsvåg H, Bergland $\AA$, Frøland O. Nødvendige omveier. En vitenskapelig antologi til Kari Martinsens 70-årsdag. Oslo: Cappelen Damm; 2013.

7. Grimen H. Profesjon og kunnskap. I: Molander A, Terum LI, red. Profesjonsstudier. Oslo: Universitetsforlaget; 2008. s. 71-86. 
8. Kunnskapsdepartementet. Rammeplan for sykepleierutdanning. Oslo: Kunnskapsdepartementet; 2008. Available at:

https://www.regjeringen.no/globalassets/upload/kd/vedlegg/uh/rammeplaner/helse/rammeplan_sykepleierutdanning_o8.pdf (downloaded 10.05.2019).

9. Forskrift 3. januar $2020 \mathrm{nr} .21 \mathrm{om}$ nasjonal retningslinje for medisinutdanning. Available at: https://lovdata.no/dokument/SF/forskrift/2020-01-03-21 (downloaded 20.09.2020).

10. Forskrift 3. januar $2020 \mathrm{nr} .16$ om nasjonal retningslinje for psykologutdanning. Available at: https://lovdata.no/dokument/LTI/forskrift/2020-01-03-16 (downloaded 20.09.2020).

11. Forskrift 15. mars 2019 nr. 409 om nasjonal retningslinje for sosionomutdanning. Available at: https://lovdata.no/dokument/SF/forskrift/2019-03-15-409 (downloaded 20.09.2020).

12. Forskrift 15. mars $2019 \mathrm{nr} .411 \mathrm{om}$ nasjonal retningslinje for vernepleierutdanning. Available at: https://lovdata.no/dokument/SF/forskrift/2019-03-15-411 (downloaded 20.09.2020).

13. Sosial- og helsedirektoratet. Psykisk helsearbeid for voksne i kommunene. Oslo: Sosial- og helsedirektoratet; 2005. Rapport IS-1332.

14. Pullon S. Competence, respect and trust: key features of successful interprofessional nurse-doctor relationships. Journal of Interprofessional Care. 2008;22(2):133-47.

15. House S, Havens D. Nurses' and physicians' perceptions of nurse-physician collaboration: a systematic review. JONA: The Journal of Nursing Administration. 2017;47(3):165-71.

16. Karlsson B, Kim SH. Sykepleie i kommunalt psykisk helse- og rusarbeid: en studie om sykepleieres rolle, funksjon og faglighet i kommunalt psykisk helse- og rusarbeid. Senter for psykisk helse og rus, Høgskolen i Buskerud og Vestfold; 2015. SFPR-rapport; 16-2015.

17. Melbye L, Ådnanes M, Kasteng F. Sykepleiere i psykisk helsevern for voksne og tverrfaglig spesialisert rusbehandling. Trondheim: Sintef; 2017. Sintef-rapport A28053.

18. Karlsen R. Profesjonell kompetanse. Sykepleien Forskning. 2009;4(3):198-204.

DOI: $10.4220 /$ sykepleienf.2009.0099

19. Olsvold N. Ansvar og yrkesrolle: om den sosiale organiseringen av ansvar i sykehus [Doctoral Thesis]. Oslo: Universitetet i Oslo, Det medisinske fakultet; 2010.

20. Kleiveland K. Sykepleierens ansvar og rolle i akuttmottak [Master's Thesis]. Høgskolen i Oslo og Akershus, Institutt for sykepleie og helsefremmende arbeid; 2014 .

21. Polit DF, Beck CT. Sampling in qualitative research. I: Essentials of nursing research: appraising evidence for nursing practice. Philadelphia: Lippincott Williams \& Wilkins; 2017. s. 491-504.

22. Kvale S, Brinkmann S: Det kvalitative forskningsintervju. Oslo: Gyldendal Akademisk; 2015.

23. Malterud K. Kvalitative forskningsmetoder for medisin og helsefag. 4. utg. Oslo: Universitetsforlaget; 2017.

24. Norsk Sykepleierforbund (NSF). Politisk plattform for psykisk helse og rus 2017-2020. Oslo: NSF; 2017. Available at: https://www.nsf.no/Content/2201713/cache=20171503104542/Revidert\%2oplattform\%2opsykisk\%20helse\%200g\%20rus\%2020172020.pdf (downloaded 15.04.2019).

25. Fause Å. Hva er sykepleie i psykisk helse- og rustjenesten? Sykepleien. 2019;107(74841):(e-74841).

DOI: $10.4220 /$ Sykepleiens.2019.74841

26. Jensen KT, Knutstad U. Slik har sykepleieforskningen utviklet seg. Sykepleien Forskning. 2019;14(75607):(e75607). DOI: $10.4220 /$ Sykepleienf.2019.75607 
27. Helles $\varnothing$ R, Larsen LS, Obstfelder A, Olsvold N. Hva er sykepleie? Sykepleien. 2016;104(8):64-6.

DOI: $\underline{10.4220 / \text { Sykepleiens.2016.58491 }}$ 